\title{
EFFECTS OF TREASURY SINGLE ACCOUNT (TSA) POLICY ON CORRUPTION IN NIGERIA
}

\author{
Olayemi Adedayo Ezekiel \\ Department of Management Science, Bamidele Olumilua University of Education, Science and \\ Technology Ikere-Ekiti, Ekiti State, Nigeria
}

Oshatimi Omowumi Olanike
Department of Accounting, Federal University Oye-Ekiti, Ekiti State, Nigeria

Article DOI: https://doi.org/10.36713/epra6409

\begin{abstract}
Corruption is one of the evil confronting the development of Nigeria. It is a cankerworm that has eaten deep into the fabrics of the Nigeria system. Various measures have been adopted by various governments and administration at all levels to combat the ugly menace. This paper assesses the effects of treasury single account (TSA) policy on corruption in Nigeria. The study found that the treasury single account (TSA) policy was introduced to block financial leakages, reduce corruption, promote transparency and prevent mismanagement of government's revenue in public sector organizations. The paper revealed that the major challenges hampering the effective and efficient implementation of the treasury single account (TSA) policy include: Inability of federal government to remit appropriately to the various agencies, uncertainties underlying federal government inactions and actions, bottlenecks/bureaucracy, internet platform delays, inefficient human capital development and time wasting in the banks and payment points. The policy will also enable the government at the centre to know its cash position at any given time without any hindrance. Therefore, it is recommended in the paper that the federal government must demonstrate the political will to ensure the sustainability of TSA policy and also tenaciously pursue its implementation by states and local governments in the country.
\end{abstract}

KEYWORDS: Treasury Single Account (TSA), Corruption, Public Sector, Organizations, Nigeria

\section{INTRODUCTION}

Treasury Single Account is a public accounting system under which all administration income, receipts and pay are gathered into one single record, usually maintained by the country's Central Bank and all payments done through this account as well (Sailendra \& Israel, 2011). The purpose is essentially to guarantee responsibility of government income, upgrade straightforwardness and keep away from misapplication of public assets. The maintenance of a Treasury Single Account will assist with guaranteeing legitimate money the board by disposing 


\section{SJIF Impact Factor 2021: 7.13| ISI I.F.Value:1.241| Journal DOI: 10.36713/epra2016 EPRA International Journal of Research and Development (IJRD)

of inactive funds usually left with various business banks and in a way to enhance reconciliation of revenue collection and payment (Adeolu, 2015).

According to International Monetary Fund, (2010), TSA is a bank account or a set of linked bank accounts through which the government carries out various business activities, and gets a statement of account of all transactions. This instrument helps the Ministry of Finance a lot as it ensures the proper management of funds available to the nation's treasury. Oyedele (2015) posited that a vital subject in the past was the delayed payment of income collected on behalf of government as some Ministries Departments and Agencies do business with those funds for their selfish gains at the detriment of infrastructural development and budget execution by the government.

The issue of corruption can be traced to the fall of man in the Garden of Eden. Corruption remains elusive and ever strives to thrive in most unlikely places. Corruption in Nigeria has become so disturbing that the former president, Chief Olusegun Obasanjo once said "the truth is that, it is much tougher to fight corruption in a developing society than it is in the developed world" (Obasanjo, 2003). Different nations have adopted different strategies to contend with corruption depending on its ramifications and depth. Whatever dimension may assume, it is certain that a nation with high incidence of corruption cannot grow or develop. This is because corruption is antithesis of growth and development, leaving in it trail negative socio-economic consequences. Corruption has brought instability, insecurity and failure of institutions (Fibadu, 2005) both the military and civilian administration so far have not faired any better than each other. Military interventions were always predicated to corruption against the civilian administration, but rather than remedy the situation, the military plundered the country resources to an unprecedented level. Thus, over the years, corruption became entrenched in government and the society. The status quo has become fashionable whereby politician and public servant see government as a means of becoming rich over night. The past administrations in Nigeria condemned and declare war against corruption; while the present administration has declared zero tolerance for corruption. Whether or not the trend is going to be reversed, is a question of time.

The approach of embracing a Single Account was accommodated in the constitution. Section 80 (1) of the 1999 Constitution as amended states "All incomes, or other cash raised or received by the Federation (not being incomes or other cash payable under this Constitution or any Act of National Assembly into some other public asset of the Federation established for a particular reason) shall be paid into and form one Consolidated Revenue Fund of the Federation"; successive governments have continued to operate multiple accounts for the collection and spending of government revenue in deliberate disregard to the provision of the constitution, which requires all government revenues be remitted into a single account (Oguntodu, Alalade, Adekunle \& Adegbie, 2016).

Organization is a social unit of people that is structured and managed to meet a need or to pursue collective goals. All organizations have an administration structure that determines relationship between the various activities and the members, and partitions and assigns jobs, obligations, and authority to do various tasks. Organizations are open systems that affect and are affected by their environment (Marshak, Thomas (2017).

The Nigerian society according to Okwoli (2004) is packed with stories of wrong practices such as ghost workers on pay roll of ministries, extraministerial department and parastatals, fraud and embezzlement of public funds. Corruption has been like a cankerworm eating deep into the fabrics of the Nigerian system, keeping the country in a terribly precarious situation, despite the huge human and natural resources it possesses. Bello (2001) also averred that there is a near total absence of the notion and ethics of accountability in the conduct of public affairs in Nigeria. This according to Bello (2001) has created a variety of loopholes that have facilitated and sustained corrupt practices which has been the bane of public sector financial mismanagement in Nigeria.

\section{CONCEPT OF TSA}

"Treasury Single Account (TSA)" has been defined from different perspective but nearly depicts the same idea. Adeolu (2015) defined Treasury Single Account as "a public accounting system under which all government revenue, receipts and income are collected into one single account, usually maintained by the country's Central Bank and all payments done through this account as well." Utilization of a Treasury Single Account will aid the management of funds and helps in of funds.

Oyedele (2015) viewed Treasury Single Account as "a unified structure of government bank accounts that gives a consolidated view of government cash resources. Based on the principle of unity of cash and the unity of treasury, a Treasury Single Account is a bank account or a set of linked accounts through which the government transacts all its receipts and payments. The principle of unity follows from the fusion of all of all money regardless of its end use. While it is important to recognize singular money 


\section{SJIF Impact Factor 2021: 7.13| ISI I.F.Value:1.241| Journal DOI: 10.36713/epra2016 EPRA International Journal of Research and Development (IJRD)

exchanges for control and detailing purposes, this intention is accomplished through the accounting system and not by holding or depositing cash in transaction specific bank accounts. This enables the treasury to delink management of cash from control at a transaction level.

Onyekpere (2015) defines Treasury Single Account as a unified structure of government bank accounts enabling consolidation and optimal utilization of government cash resources. It is a bank account or a set of linked bank accounts through which the public authority executes every one of its receipts and payments and gets a consolidated view of its cash position at any given time. This presidential directive would end the previous public accounting situation of several fragmented accounts for government revenues, incomes and receipts, which in the recent past has meant the loss or leakages of legitimate income for the federation account.

Nelson, Adeoye and Ogah (2015) are of the opinion that Treasury Single Account is an account that all ministries and government departments" account balances are collated by the Central Bank, whereas there is an intermediate account for every ministry and department that shows the total of all debt and credit transactions. Thus, the total amount will be reflected eventually on the treasury single account at the end of the day.

Chukwu (2015) define Treasury Single Account (TSA) as a network of subsidiary account linked to a main account such that, transactions are effected in the subsidiary accounts but closing balances on these subsidiary accounts are transferred to the main account, at the end of each business day. Therefore, Ministries, Departments and Agencies (MDAs) keep up their individual records with the money deposit banks, yet every day financing of their payment are made using the central or main account, which is resident with the Central Bank, just as their closing balances at the end of day are transferred to the main account.

The TSA is principally a cash management tool for efficient management of the cash position. Prior to the implementation of the TSA, government was incurring finance cost on debit balances in some MDA's accounts while it was earning close to nothing on the credit balances of other MDAs. With the TSA, the net balances on all the MDA accounts now reside with the Central Bank; hence, the government avoids incurring interest costs when it has positive net position (Eme et al, 2015).

\section{TREASURY SINGLE ACCOUNT (TSA) IN NIGERIA}

The Treasury Single Account (TSA) strategy was acquainted with block monetary leakages, promote transparency and forestall blunder of government's income, brings together all administration accounts, empowering it forestall income loss and mismanagement by revenue-generating agencies (Bashir, 2016). Firstly is a unified structure of government bank accounts enabling consolidation and optimal utilization of government cash resources? Through this bank account or set of linked bank accounts, the public authority executes every one of its receipts and payments and gets a consolidated view of its cash position at any given time. The expectation of executing this account was for the advantages of Federation ruled by democracy.

In 2012, it was on record that government ran a pilot scheme for a single account using 217 ministries, department and agencies as a test case. The exercise saved Nigeria about N500 billion in frivolous spending. The accomplishment of the pilot roused the public authority to actualize completely TSA, prompting the mandates to banks to give the innovation stage that will assist with obliging the TSA as it encourages ideal and more complete bookkeeping reports (Gwarzo, 2016).

Section 80 (1) of the 1999 Constitution as amended states that "all revenue or other money raised or received by the Federation (not being revenue or other money payable under this Constitution or any Act of the National Assembly into any other public fund of the Federation established for a specific purpose) shall be paid into and form one Consolidated Revenue Fund of the Federation". Successive governments have continued to operate multiple accounts for the collection and spending of revenue, thereby disregarding the provision of the constitution which require the remittance of all the revenue into a single account.

\section{Effects of Treasury Single Account (TSA) in Combating Corruption}

The adoption of TSA in Nigeria has helped the federal government has it pools and unifies all government accounts through a single treasury account. The advantages and benefits of the Treasury Single Account are numerous. The consolidation into a Treasury Single Account paves way for timely capture and payment of all due revenues into government coffers without the intermediation of multiple banking arrangements and this has contributed in no small measure in waging war against corruption . Establishing a unified structure of government bank 


\section{SJIF Impact Factor 2021: 7.13| ISI I.F.Value:1.241| Journal DOI: 10.36713/epra2016 ISSN: 2455-7838(Online) EPRA International Journal of Research and Development (IJRD)

accounts via a treasury single account (TSA) will solve these problems, improving cash management and control. It should therefore, receive priority in any public financial management (PFM) reform agenda. A TSA also facilitates better fiscal and monetary policy coordination as well as better reconciliation of fiscal and banking data, which in turn improves the quality of fiscal information. Finally, the establishment of an effective TSA significantly reduces the debt servicing costs (International Monetary Fund, 2010).

According to Pattanayak and Fainboim (2010), the primary objective of a TSA is to ensure effective aggregate control over Government cash balances. Other objectives for setting up a TSA are as follows:

$>$ Minimizing transaction costs during budget execution, notably by controlling the delay in the remittance of government revenues (both tax and nontax)

$>$ Controlling the delay in the remittance of government revenues by collecting banks, in both tax and non-tax;

$>$ Making rapid payments of government expenses;

$>$ Facilitating reconciliation between banking and accounting data;

$>$ Efficient control and monitoring of funds allocated to various government agencies; and

$>$ Facilitating better coordination with the monetary policy implementation

\section{Benefits of Treasury Single Account (TSA)}

(Pattanayak, 2010) in a The International Consortium on Governmental Financial Management (ICGFM) seminar elaborated on TSA and its usefulness for any government. According to him TSA aids cash management, and facilitates other functions such as handling payment from all spending units separately, unlike the multiple bank account system. TSA a single account comprising of linked up accounts or can be seen as network of account $\mathrm{s}$ operated as one, this account is usually operated by the country's central bank. It is also a unified structure of government bank accounts that gives a consolidated view of government cash resources. The emphasis is placed of the mode of operation as well as the cash control advantage and elimination of idle funds it has.

The Benefits of the Treasury Single Account (TSA) include:

$>$ Ensures complete, real-time information on government cash resources

$>$ Helps preparation of accurate and reliable cash flow forecasts

$>$ Optimizes the cost of government operations

$>$ Facilitates efficient payment mechanisms
$>$ Improves operational and appropriation control during budget execution

$>$ Enhances efficiency and timeliness of bank reconciliation

\section{Advantages of Treasury Single Account (TSA)}

According to Bashir, (2016) offers several advantages of TSA;

$>$ Provides a safe haven for government cash deposits which minimizes credit risk exposure.

$>$ Aids the efficient management of government liquidity, and facilitates the central bank's coordination of its monetary policy operations in managing liquidity in the economy with government's cash and debt management functions.

$>$ Can facilitate cost effective banking arrangements and speedy settlements (it might be possible to negotiate with the central bank to act as the clearing house for government operations, which may speed settlement).

$>$ Allows for clarity of banking arrangements and remuneration policies between the treasury and the central bank (a service level agreement is normally negotiated to clarify obligations and responsibilities when the central bank acts as the clearing house for government operations).

\section{CONCEPT OF CORRUPTION}

Corruption may not be easy to define. There is no universal agreement on what constitute corruption. Be that as it may, some researchers have differently defined corruption. According to Tanzi (2008), "corruption is by and large not hard to perceive when noticed." The most simplified and the famous definition is that embraced by the World Bank, which defines corruption as the abuse of public power for private benefits (Gray and Kaufman 2008)

Regardless, the alternate points of view through which corruption might be seen, a shared belief of assessment imagines it as the execution of a bad habit against the public prosperity. Lipset and Lenz (2000) defining corruption in the above line maintained that it is an effort to secure wealth or power through illegal means for private gains at public expense. In recent years, increasing attention has been devoted to understanding the reasons for and consequences of corruption. The existing literature can be divided into two broad strands.

Corruption like most concepts in social sciences is classified into the group of concept described by Gallie (2016) as highly contestable concepts. Thus, the definition that may be attached can 


\section{SJIF Impact Factor 2021: 7.13| ISI I.F.Value:1.241| Journal DOI: 10.36713/epra2016 EPRA International Journal of Research and Development (IJRD)

be dissected and restricted. Otite (2016) defined corruption as "the perversion of integrity or affairs through bribery, favour, or moral depravity... societal impurity" (cited in Okafor, 2009). Lipset and Lenz (2000) define corruption as an "effort to secure wealth or power through illegal means for private gain at public expense" (Fagbadebo, 2007).

Corruption, according to Nkom (2012) is the perversion of public affairs for private advantage. Nkom was also of the view that corruption includes bribery or the use of unauthorized rewards to influence people in position of authority either to act or refuse to act in ways beneficial to the private advantage of the giver and then that of the receiver. It includes the misappropriation of public funds and resources for private gains, nepotism etc. In a similar vein, Doig (2016) described corruption as, the use of official position, resources or facilities for personal advantage, or possible conflict of interest between public position and private benefit. This involves misconduct by public officials and usually covered by a variety of internal regulations (Public Service Rules and Extant Rules).

According to Andrig and Fjelstad (2001) viewed corruption as a "mind boggling and multifaceted wonder with numerous circumstances and end results, as it takes on different structures and settings". According to them, one of the significant troubles in conceptualizing debasement is that while it is hard to vanish it has an ability to take on new structures (Andrig and Fjelstad, 2001). In a similar fashion, Tanzi (2008) maintains that while it is difficult to define corruption, the crisis associated with corruption is not difficult to recognize.

\section{THE CAUSES OF CORRUPTION IN NIGERIA}

A number of factors have been identified as instrumental to enthroning corrupt practices especially in developing countries. Some evidence substantiate that they have the following link: political and cultural variables, social diversity, ethno-linguistic fractionalization, and the proportion of a country's population adhering to different religious traditions. Thus, the sociopolitical economy system and the culture of a society could make the citizens more prone to corrupt activities.

According to Epele, (2006), the fundamental factors that have engender and sustained corrupt practices in Nigeria include:

$>\quad$ The weak institutions of government;

$>\quad$ Political office as the primary means of gaining access to wealth;

$>\quad$ Conflict between changing moral codes;
$>$ The weakness of social and governmental enforcement mechanism;

$>$ The absence of a strong sense of national community;

$>\quad$ Dysfunctional legal system;

$>$ Less effective government works with slow budget procedures;

\section{$>\quad$ Lack of transparency;}

$>\quad$ The great inequality in the distribution of wealth;

$>\quad$ Low salaries and poor working conditions, with few incentives and rewards for efficient and effective performance;

$>\quad$ Influence or pressure of 'polygamous household' and extended family system, and pressure to meet family obligations, which are more in Less Developed Countries;

$>$ The culture and weird value systems of the Nigerian society. Becoming corrupt is almost unavoidable, because morality is relaxed in the society, and many people struggle for survival without assistance from the state;

$>\quad$ Widespread poverty.

\section{EFFECT OF CORRUPTION ON PUBLIC SECTOR FINANCIAL PERFORMANCE}

The outcomes of corruption on a country's socio-political and economic improvement are myriad. The foremost impact of corruption is that it prompts a decrease in economic development and improvement by bringing motivators down to invest, it likewise prompts a divestment in such economies. Genuine investors are consistently careful about contribution pay-offs prior to being permitted speculation rights or operational licenses. This is because of the way that there is no assurance that lubed authorities may keep their side of the understanding, and with no authority cover they address in the event of agreement penetrate, the fleeced financial investor is all alone (Epele, 2006). To the above is the fact that foreign investors are also prone to withdraw their capital from a country with high incidence of corruption because the risk involved in doing business in such nations sometimes outweighs the benefits. Granted that it has been argued that corruption provides both local and foreign investors the leverage to surmount bureaucratic impediments, yet the number of such successful deals is a far cry from the avalanche of investors that have stripped off their hardearned money (Keeper, 2010).

Corruption also alters the pattern of government expenditure. Experience has shown that in highly corrupt countries, officials throw government funds more into large and hard-to manage projects, such as airports or highways than on social services like health and education. It has been a stumbling block 


\section{SJIF Impact Factor 2021: 7.13| ISI I.F.Value:1.241| Journal DOI: 10.36713/epra2016 EPRA International Journal of Research and Development (IJRD)

to people enjoying the social fruits of good governance (Ibrahim, 2003). Corruption contributes immensely to inhibition of economic performance; it negatively affects investment and economic growth, which is detrimental to national development. If corruption discourages investment, limits economic growth and alters the composition of government spending, it automatically hinders future economic growth and sustainable development.

Corruption undermines development by distorting the rule of law and weakening the institutional foundation on which economic growth depends. Corruption is not peculiar to developing nations alone. It is a plague that affects both developed and developing economy, although the occurrence in developing societies like Nigeria seems to be pervasive. Dada (2014) declared that corruption is by all accounts the most mainstream issue examined as a reason for underdevelopment in Nigeria today. Pretty much every segment of the nation is influenced by corruption going from education sector to the different organs of government. Corruption is the biggest single inhibitor of fair monetary improvement in numerous nations of the world including Nigeria.

Corruption tarnished the image of a country; maybe, Nigeria experiences more than most social orders a shocking global image made by its powerlessness to manage pay off and debasement. For example, the 1996 investigation of defilement by the Transparency International and Goettingen University positioned Nigeria as the most corrupt country among the 54 countries on the study, with Pakistan as the second highest (Moore, 2017). In the 1998 Transparency International Corruption Perception Index (CPI) survey of 85 countries, Nigeria was ranked 81 (Lipset and Lenz 2000). Worse still, in the 2001 Corruption Perception Index (CPI) survey of 85 countries, the image of Nigeria slipped further south, as The Transparency International Corruption Index, 2001 ranked Nigeria 90 out of the 91 countries studied (second most corrupt nation in the world) with Bangladesh coming first.

\section{PUBLIC ORGANIZATIONS ADMINISTRATION}

Public organizations are government Ministries, Departments and Agencies (MDAs). Some MDAs generate revenue while others does not. Funds are needed to carry out some huge and elementary administrative functions in MDAs. Probably, some MDAs hitherto sponsored these administrative functions from funds generated to meet up with deadline and ensure efficiency. However, the evolution of the TSA Policy in 2015 marked a new era.
Currently, MDAs apply for funds from the government for all administration expenditure. It is not unlikely that it might take some time before MDAs receives the requested funds. The MDAs will probably experience some administrative challenges and inefficient performance when funds requested are not provided or provided at a very late hour (Eme, Chukwurak \& Iheanacho, 2015).

In the same vein, Utsu, Muhammed, and Obukeni (2016) noted that the Nigerian University System (ASSU) believed that their financial independence that TSA deprived them off is extremely central for the effective performance and administrative efficiency of university system in Nigeria. It has also been observed that the financial institutions but commercial banks specifically were not better off since the implementation of TSA. This is because public sector funds constitute a huge portion of commercial banks deposit.

\section{CONCLUSION}

The policy will greatly improve the management of government revenue. Corruption is a cankerworm that hinders development in any society. Introduction of a Treasury Single Account in Nigeria is a key element of an efficient and effective public financial management system and an essential tool for minimizing government and frivolous spending which was introduced by the federal government of Nigeria to fight against corruption. Besides, the system will likely reduce the mismanagement of public funds by revenuegenerating agencies. It is also expected to help check excess liquidity, inflation, high interest rates, roundtripping of government deposits, and the sliding value of the naira.

\section{Recommendations}

The following recommendations were made:

$>$ For the success of the treasury single account policy, government should engage in massive public enlightenment about the important of the policy. Government should overhaul the capacity of the Federal Ministry of Finance and the CBN to cope with challenges associated with enforcement of the provisions of the TSA.

$>$ For the treasury single account (TSA) policy to be effective the Fiscal Sunshine Bill needs to be put in place, which if enacted will open up the financial activities of government in a manner that there will be no seriously concealing spot for the individuals who divert or loot government money. For example, with Fiscal Sunshine Act in place, budgeting process and implementation, including contract awards, ought to be in the open for 


\section{SJIF Impact Factor 2021: 7.13| ISI I.F.Value:1.241| Journal DOI: 10.36713/epra2016 EPRA International Journal of Research and Development (IJRD)}

Nigerians to see both how incomes are generated and how open money is being spent by those in government, and why.

$>$ The ineffectiveness in public sector administration resulting from TSA installation should be investigated and lasting solution administered by the government.

$>$ There should be an incessant sensitization of relevant stakeholders on the necessities for TSA.

$>$ In order ensure the success of the TSA policy, the federal government must demonstrate the political will to ensure the sustainability of the TSA policy and also tenaciously pursue the implementation of TSA by state and local governments in the country.

\section{REFERENCES}

1. Adeolu I.A. (2015). Understanding the Treasury Single Account (TSA) System - Things You Should Know. Business \& Economy, Market Development.

2. Andrig, J. \& Fylestad, K. (2001). The imperatives of prudent management of Nigeria's resources. International Journal on Governmental Financial Management, 9(1), 67-86.

3. Bashir, A. (2016). "New System of Public Sector Budgeting: A Technique and Strategy for the Development of Nigeria's Economy, International Journal of Economic and Development Issues, 8(1 \& 2): $118-129$.

4. Bello, S. (2001). Fraud Prevention and Cotrol in Nigeria Public Service: The need for a Dimensional Approach. Journal of Business Administration, 1(2), 118-133.

5. Chukwu, I. (2015). Can Treasury Single Account (TSA) Work in Nigeria? Vanguard Editorial Newspaper, August 16; 33-35. Constitution of the Federal Republic of Nigeria, 1999 as Amende

6. Dada, S. (2014). Forensic Accounting Technique: A means of Successful Eradication of Corruption through Prevention, Bribery Prevention and Embezzlement Prevention in Nigeria. Arabian Journal of Business and Management review, 4(1), 176-186.

7. Dong, B. (2016). The causes and Consequences of Corruption A thesis Presented to the School of Economics and Finance, of Economics and Finance, Queensland University of Technology.

8. Eme, O. I., Chukwurak, D. C., \& Iheanacho, E (2015). An Analysis of Pros and Cons Treasury Single Account Policy in Nigeria. Arabian Journal of Business Management Review (OMAN Chapter), 5(4): 20-39.

9. Epele, A. (2006). Corruption and the Nigerian Society: Causes, Effects and the Futility of Solutions. The Politics Magazine. University of Benin. Benin City.

10. Fagbadebo, H. (2007). Can E-Governance make Public Governance more Accountable in Shah, A.
(ed).Performance Accountability and Combating Corruption, World Bank. Retrieved on 2/8/2015 from http://worldbank.org

11. Fibadu, R. (2005). The Role of Political Institutions in Promoting Accountability" in Shah, A. (ed) "Performance Accountability and Combating Corruption", World Bank. Retrieved on 2/4/2011 from http://worldbank.org.

12. Gallies, S. (2016): "How to Increase Productivity" Modem Business Report. Chicago, Alexander Hamilton Institute, Pp. 72-81.

13. Gray C.W. and Kaufman D. (2008), 'Corruption, Culture and Market,' in Lawrence Harrison and Samuel P. Huntington (eds), Culture Matters, New York Basic Books.

14. Gwarzo. M. (2016)., TSA: Weep Not SEC. This day live

http://www.thisdaylive.com/index.php/2016/03/09/t sa-weep-not-sec/ retrieved March, 2016.

15. Ibrahim, J. (2003). Corruption in Nigeria: Transition, Persistence and Continuity. The Nigerian Social Scientist, 2.

16. International Monetary Fund (IMF). (2010). Treasury Single Account: Concept, design, and implementation issues. IMF Working Paper $W P / 10 / 143$

17. Keeper, L. (2010): Systemic Corruption in Nigeria: A Threat to Sustainable Development. Proceedings of the 1st International Technology, Education and Environment Conference (c) African Society for Scientific Research (ASSR), CoPublished By: Human Resource Management Academic Research Society. www.hrmars.com/admin/pics/224.pd

18. Lipset, S. M. and Lenz, G. S. (2000): Corruption, Culture, and Markets, in Culture Matters, Lawrence E. Harrison, and Samuel P. Huntington, eds., (New York: Basic Books, 2000), p.112.

19. Marshak, M. \& Thomas, P. (2017). Working Capital Management and Profitability - Case of Pakistani Firm. International Review of Business Research Papers, 3(1), 279-300.

20. Marshak, Thomas (2017). "Organization Theory," The New Palgrave: A Dictionary of Economics, v. 3, pp. 757-60.

21. Moore, S. (2017): Power and Corruption, Visions Paperback, 2017.

22. Nelson, C., Adeoye, T. \& Ogah, D. (2015). Treasury Single Account; Giving Life to Jonathan's Dead Policy Directives. Sunday Guardian Newspaper, 52-58.

23. Nkom, C (2012). Treasury Single Account, ,ll block leakages", Vanguard, August 24, 38 International Federation of Accountants (2001). Governance in the Public Sector: A Governing Body Perspective. International Public Sector Study. Retrieved on 2/4/2011 from http://www.ifac.org

24. Oguntodu, J.A, Alalade, Y.S.A, Adekunle, Y.A. \& Adegie, F.F. (2016). Treasury Single Account and Nigeria Economy Between 1999 and 2015: An 
Assessment. Journal of Accounting and Financial Management. 2(6), 61-75.

25. Okofor, R. (2007). The Role of Political Institutions in Promoting Accountability" in Shah, A. (ed) "Performance Accountability and Combating Corruption”, World Bank. Retrieved on 2/4/2011 from http://worldbank.org.

26. Okwoli, A. (2004). Towards probity, accountability, and transparency in revenue generation in the Nigerian public sector. Nigerian journal of Accounting Research, 1(1), 1-9.

27. Olusegun Obasanjo (2003). Fight Corruption in a Developing Society than it is in the Developed World. World Bank International Public Sector Study. Retrieved on 2/4/2011 from http://www.ifac.org

28. Onyekpere, L. (2015, August 9). Buhari orders federal ministries, agencies to open treasury single account. The Punch Newspaper, p. 61.

29. Otite, O. (2016) "On the Sociological Study of Corruption" in Femi Odekunle (ed) Nigeria: Corruption in Development Being the Proceedings of the Nigerian Anthropological and Sociological Association, held in Zaria, 10-13 May, 1982, pp 1119.

30. Oyedele, T. (2015). Treasury Single Account and Taxation" PWC Nigeria. Retrieved from http://pwcnigeria.typepad.com/files/tsa-and-tax--part-1-bizday.pdf Journal of Accounting and Financial Management: ISSN 2504-8856 Vol. 2 No. 62016 www.iiardpub.org IIARD - International Institute of Academic Research and Development, 75.

31. Pattanayak S. (2010), Treasury Single Account: Concept, Design and Implementation. IMF Working Paper, May 2010, 1-47.

32. Pattanayak, S. \& Fainboim, I. (2010). Treasury Single Account: An Essential Tool for Government Cash Management. IMF Working Paper Technical Notes and Manuals.

33. Sailendra P, and Isreal F. (2011). Treasury Single Account: An Essential Tool for Government Cash Management Fiscal Affairs Department (IMF Working Paper).

34. Tanzi V. (2008), 'Corruption, Arm's Length Relationship and Market' in Forientian and Sam Peltsman (ed), The Economics of Organised Crime, Cambridge University Press, London.

35. Utsu E.A., Muhammed, M.B. \& Obukeni, C.O. (2016). An Assessment of the Treasury Single Account Policy on Nigeria Economy. Social Sciences Journal of Policy Review and Development Strategies. 2(1), 74-82. 